\title{
THE EFFECTIVE USE OF VOLUNTEERS: BEST PRACTICES FOR THE PUBLIC SECTOR
}

\author{
JEFFREY L. BRUDNEY*
}

I

INTRODUCTION

Several myths surround the involvement of volunteers in public and nonprofit organizations in the delivery of services. ${ }^{1}$ Perhaps the most common are that volunteers are "free" or impose no monetary costs on the host organization, and that they can "save" agencies teetering on the edge of financial ruin. ${ }^{2}$ Nearly as common is the assertion that volunteers cannot be "fired" or, in more extreme form, cannot be managed." Other myths include beliefs that volunteers will perform any job task, and that they are readily available to all organizations that want them. ${ }^{4}$ Volunteer programs have the lamentable drawback, however, that they engender adversarial relationships with paid staff. ${ }^{5}$

Like most myths, those pertaining to volunteer involvement contain a grain of truth. Programs that have not been designed carefully are likely to fall prey to the identified maladies and worse. ${ }^{6}$ Alternatively, in programs that have been structured carefully, volunteer participation can help agencies realize the benefits and avoid the pitfalls of using volunteers. The most successful programs implement mechanisms and procedures to administer the volunteer effort and manage its novel human resources effectively.

Copyright ( 2000 by Jeffrey L. Brudney

This article is also available at http://www.law.duke.edu/journals/62LCPBrudney.

* Professor, Department of Political Science, University of Georgia.

I am grateful to Nancy Macduff for collection and use of the data analyzed herein. I thank Professor Charles T. Clotfelter for his comments and suggestions.

1. See, e.g., Jeffrey L. Brudney, The Involvement of Volunteers in the Delivery of Services: Myth and Management, in PUblic Personnel Administration: Problems and Prospects (Steven W. Hays \& Richard C. Kearney eds., 1995).
2. See id. at 324 .
3. See id. at 322.
4. See id. at 320.
5. See id. at 327.
6. See id. at 322 .
7. See id. at 322-23. 
Although for the most part the academic literature has not considered the issue of best practices in volunteer program design and administration, ${ }^{8}$ much of the practitioner literature describes in detail the characteristics of a thriving volunteer program. Based on a large sample survey of volunteer programs in public agencies, this article attempts to provide tentative evidence of the frequency of these best practices in public agencies. The article posits a relationship between best practices and the benefits realized from volunteer involvement. In considering this analysis, the reader should be aware of two factors. First, because validated measures of volunteer performance do not exist, the measures of benefits used here emanate from the perceptions of the program directors. Second, because the parameters of the population of volunteer programs in government are unknown, the sample of programs analyzed here cannot be said to be representative.' Nevertheless, the sample is large and heterogeneous, and previous research has not systematically examined the efficacy of the purported best practices, despite the manifest need to do so.

The next two sections of the article present the necessary background. Part II defines government-based volunteer programs to delimit the empirical analysis, and Part III examines the extent and scope of volunteer involvement in the public sector. Part IV discusses the elements that contribute to best practices with volunteer workers. The article then considers in Part V the data collected from the sample of government-based volunteer programs and the methods used in their analysis, and presents and interprets the empirical findings in Part VI. The article concludes with a summary and discussion of the implications of the research.

\section{II}

\section{Defining Volunteer Programs In THE Public SeCtor}

The definition of "volunteer" and related concepts such as volunteerism, or voluntarism, is controversial. In an early treatment of the concept, David Horton Smith noted that "[v]oluntarism represents a category of human activity that is so varied it defies adequate description... . Yet we can only hope to deal rationally with this great variety of activities if we can devise some shorthand ways of referring to major sub-types of volunteers and voluntarism." ${ }^{10}$ Some twenty years later, reviewing the voluminous literature in the field-more than 300 articles and reports-Ram A. Cnaan and colleagues uncovered a great

8. But see, e.g., JefFrey L. Brudney, Fostering Volunteer Programs in the Public Sector: PlanNing, Initiating, and Managing Voluntary ACtivities (1990); Jone L. PEARCE, VolunteErs: The ORganizational Behavior of UnPaid Workers (1993); David Horton Smith \& Ce Shen, Factors Characterizing the Most Effective Nonprofits Managed by Volunteers, 6 NONPROFIT MGMT. \& LEADERSHIP 271 (1996).

9. I am grateful to Charles T. Clotfelter for pointing out that if more about that population were known, the sample could be weighted appropriately to reflect those parameters. 1972).

10. David Horton Smith, Types of Volunteers and Voluntarism, 6 VOLUNTEER AdMIN. 3 (Sept. 
many interpretations of the volunteer concept, constituent dimensions, and measurement methods and indicators. ${ }^{11}$ They concluded that, "[a]lthough most scholars agree on the importance of volunteerism, there is little consensus as to what is, and is not, volunteerism. Therefore, it is important that the boundaries of volunteerism be explicitly and clearly defined." 12 For present purposes, a definition of government-based volunteer programs is needed to elucidate the areas in which volunteers assist government agencies, the magnitude of this effort, and the managerial and program elements involved in volunteer administration and attendant best practices.

In their analysis of the extensive research on volunteering, Cnaan et al. conclude that four principal dimensions underlie the definition of the volunteer concept. ${ }^{13}$ The first is "free choice," or the degree to which the decision to volunteer is free or uncoerced. ${ }^{14}$ Popular conceptions of the term "volunteer" notwithstanding, pressure to donate time is hardly unknown in the volunteer world. For example, schools in California apparently pressure parents to volunteer on campus as well as to make monetary donations. ${ }^{15}$ In addition, an increasing number of elementary and secondary school systems require community-service experiences for graduation, and most encourage their students to undertake service activities. ${ }^{16}$ The decision to volunteer also may be obviated, for example, by a court order mandating service as part of a legal sentence often called "community service."

The second dimension is the nature of remuneration, if any, received by the volunteer. ${ }^{17}$ Remuneration can range from none at all, to reimbursement for expenses incurred in the activity, ${ }^{18}$ to a stipend or minimal pay given to participants, as in the AmeriCorps program. ${ }^{19}$ At the other end of the spectrum and rarely considered in definitions of the concept, the volunteer might be required to pay for the privilege in certain instances. For example, the volunteer might be required to make a financial contribution to a prestigious nonprofit organization, such as a renowned cultural institution, in return for a

11. See generally Ram A. Cnaan et al., Defining Who Is a Volunteer: Conceptual and Empirical Considerations, 25 NONPROFIT \& VOluntARY SECTOR Q. 364 (1996); Ram A. Cnaan \& Laura Amrofell, Mapping Volunteer Activity, 23 NONPROFIT \& VOLUNTARY SECTOR Q. 335 (1994).

12. Cnaan \& Amrofell, supra note 11, at 337.

13. See Cnaan et al., supra note 11, at 369; Eleanor Brown, The Scope of Volunteer Activity and Public Service, 62 LAW \& CONTEMP. PROBS. 17 (Autumn 1999).

14. See Cnaan et al., supra note 11, at 369.

15. See Tanya Schevitz, Schools Pressuring Parents: Public, Private Campuses Want More Volunteers, Donations, S.F. Chron., Sept. 23, 1997, at A1.

16. See generally Sally A. Raskoff \& Richard A. Sundeen, Community Service Programs in High Schools, 62 LAW \& CONTEMP. PROBS. 73 (2000).

17. See Cnaan et al., supra note 11 , at 370 .

18. See id.

19. See Brown, supra note 13 , at 18 .

The definition also extends to stipended volunteers. As the word "stipend" implies, programs such as AmeriCorps offer modest pay to doers of good works, on the theory that society needs full-time volunteers and that it is hard for very many people to give so much time freely and continue to keep body and soul together. 
seat on its board of directors. It would be a rare nonprofit organization that did not expect members of its voluntary board of directors to make a monetary contribution.

Third is the context or auspices under which the volunteer activity takes place. $^{20} \quad$ Volunteering may be informal and outside of an organization (for example, helping a neighbor or friend). Alternatively, volunteering may occur in a formal, organized setting, which is almost always a nonprofit organization or government agency. ${ }^{21}$ Volunteering to profit-making firms does occur, but its legal status is debatable. For example, a New York Times article reported that America Online had used volunteers for a decade to help maintain its online services-by answering questions from subscribers, supervising chat rooms, and enforcing rules-and that some former volunteers had challenged the practice under the Fair Labor Standards Act ("FLSA"). ${ }^{22}$

In their analysis of definitions of volunteering, the final dimension identified by Cnaan et al. is the intended beneficiaries of the activity. ${ }^{23}$ The aim of volunteers may be to benefit or help strangers, friends, relatives, themselves, or some combination of these beneficiaries. ${ }^{24}$

These dimensions for classifying volunteer activity illustrate the great breadth of the concept and the need to delineate the nature of volunteering under consideration. ${ }^{25}$ Each combination of dimensions yields a distinct conception of volunteering with important implications for volunteer-program design and management. Rather than summarily combine all forms of volunteering as if they were identical or nearly so, Cnaan and Laura Amrofell maintain that "only the combination of all facets forms a volunteer profile that is distinctive enough to warrant generalizations." 26

In this article, the focus is on volunteer programs in the public sector. Volunteering to the public sector has the following characteristics:

(1) The volunteer activity is sponsored and housed under the auspices of a government agency.

(2) As implied by this definition, the volunteer activity takes place in a formal setting, that is, in an organizational context.

(3) The volunteers do not receive remuneration for their donations of time and labor. Based on their study of the AmeriCorps program,

20. See Cnaan et al., supra note 11 , at 370.

21. See id.

22. See Lisa Napoli, America Online is Facing Challenge Over Free Labor, N.Y. TIMES, Apr. 14, 1999, at A18. According to Peter J. Eide, the FLSA stipulates that if a person is considered a volunteer and accordingly is not paid wages, and it is later determined by the Department of Labor, which administers the FLSA, or a court of law that she or he should have been a paid employee, the employer could be liable for at least minimum wages for all hours worked, including overtime. See Peter J. Eide, Volunteers and Employment Law, in THE VOLUNTEER MANAGEMENT HANDBOOK 339, 345 (Tracy Daniel Connors ed., 1995).

23. See Cnaan et al., supra note 11 , at 370 .

24. See id. at 371.

25. See Cnaan \& Amrofell, supra note 11, at 349.

26. See id. 
Debra Mesch et al. maintain that they "see the stipended volunteer as conceptually and behaviorally different from the uncompensated volunteer." ${ }^{27}$ This article follows their approach.

(4) Volunteers in the public sector are entitled to reimbursement for the out-of-pocket expenses incurred in this activity, such as mileage, meals, and parking. Although stipended volunteers are excluded from the definition, one should not have to "pay" for the privilege of volunteering. The FLSA provides that individuals do not lose their status as volunteers merely because they receive reimbursement. ${ }^{28}$ The degree to which government agencies honor this principle is an empirical matter, to be examined below.

(5) The volunteer's time should be given freely, rather than mandated or coerced. Compulsion significantly alters the nature of volunteering. ${ }^{29}$ Regulations issued under the FLSA by the U.S. Department of Labor state that volunteer services should be offered freely and without pressure or coercion. ${ }^{30}$

(6) The volunteer activity is intended to benefit the clients of government agencies, although participants may certainly reap nonmaterial benefits as well (for example, psychic and social benefits), and almost surely do.

(7) Government-based volunteer programs place citizens in positions with ongoing responsibilities for service-delivery (for example, client contact) or organizational maintenance (for example, assisting paid staff). "There are no limitations or restriction imposed by the FLSA on the types of services which private individuals may volunteer to perform for public agencies." ${ }^{11}$

27. Debra J. Mesch et al., Altruists or Egoists? Retention in Stipended Service, 9 NONPROFIT MGMT \& LEADERSHIP 3, 4 (1998).

28. See Eide, supra note 22, at 344.

29. See Jon VAn Til, Mapping the Third Sector: Voluntarism in a Changing Social ECONOMY 6 (1988).

30. See Eide, supra note 22, at 343.

31. See id. (quoting 29 C.F.R. § 55.3.104(a)). Governments have taken full advantage of this latitude by enlisting volunteers in a great variety of capacities, including ombudsperson, courtappointed advocate, driver, food preparer and deliverer, counselor, psychologist, recreation assistant, accountant, budget assistant, mentor, library docent, computer programmer, data entry technician, building inspector, hot line operator, energy auditor, legal aide, emergency medical technician, park ranger, teacher's aide, museum guide, police auxiliary, chaplain, fire fighter, recycling specialist, and a host of other jobs. For an illustrative listing of some-but by no means all-of the ways in which governments involve volunteer workers, see NATIONAL ASSOCIATION OF COUNTIES, THE VOLUNTEER TOOLBOX: A GUIDE TO VOLUNTEER PROGRAMS IN COUNTY GOVERNMENT 3-4 (1997) and CHERYL A. FARR, VOLUnTEERs: MANAging VOlUnTEER PERSONNEL IN LOCAL GovernMENT 9-10 (1983). Lydia D. Manchester and Geoffrey S. Bogart describe many other uses of volunteer workers by governments, including detailed descriptions of programs. See LYDIA D. MANCHESTER \& GEOFFREY S. BOGART, CONTRACTING AND VOLUNTEERISM IN LOCAL GOVERNMENT: A SELF-HelP GUIDE 73-82, 139-216 (1988). For a more recent description of the many ways in which governments continue to involve volunteer workers, see generally Volunteer Programs in Cities and Counties, 31 InTERnATIONAL CITY/COUNTY MANAGEMENT ASSOCIATION SERVICE REPORT 1 (Aug. 1999). 
Based on this definition, the inquiry turns to the extent and scope of volunteering to government organizations and the management of these programs.

\section{III}

\section{THE EXTENT AND SCOPE OF VOLUnTEERING TO THE PUBLIC SECTOR}

Several surveys and other data offer useful insights into the extent of volunteering in the public sector in the United States and the substantive foci of this activity. These studies establish that although the great majority of volunteers donate their time to the nonprofit sector, a significant amount of volunteering is devoted to goverment organizations.

The Nonprofit Almanac 1996-97 compiles findings from biennial national surveys conducted by the Gallup Organization and from additional sources on charitable giving and volunteering by Americans. ${ }^{32}$ The three most recent Gallup surveys that systematically analyzed whether the respondent had volunteered to a government organization were conducted in 1992, 1990, and 1988. All of the surveys are retrospective, directing respondents to consider activities of the previous year. The Almanac presents only fragmentary, preliminary data for volunteering in government organizations in 1993 and none at all for a 1995 Gallup survey on volunteering.

Table 1 summarizes findings from the 1992, 1990, and 1988 surveys pertaining to volunteer involvement in government. In the 1992 survey, 26.6\% of volunteers reported donating time to a government organization. ${ }^{34}$ By contrast, two-thirds indicated that they had contributed time to a nonprofit organization. ${ }^{35}$ As Table 1 demonstrates, this level of reported volunteering to government is consistent with the results of the two earlier surveys. According to the 1992 survey, about one-quarter of all hours volunteered, or $25.3 \%$, went to government organizations, again a figure that was consistent across the three surveys. $^{36}$ The assigned dollar value of this contribution was a staggering $\$ 55.1$ billion, up some eleven billion dollars from the 1990 survey. ${ }^{37}$ Similarly, the preliminary results from the 1994 Gallup survey show that when volunteer hours are converted to a full-time equivalent basis $(1,700$ hours of work per year) ${ }^{38}$ government accounted for $26.1 \%$ of all volunteer employment. ${ }^{39}$ This

32. See Virginia A. Hodgkinson et Al., Nonprofit Almanac, 1996-1997: Dimensions of THE INDEPENDENT SECTOR 4 tbl. 1.4 (1996).

33. See id. at 29-30. The 1993 data was based on a 1994 Gallup survey, and the 1995 data upon a 1996 Gallup survey. The full reports on the 1994 and 1996 surveys do not present items or findings pertaining to volunteering to government. See generally VIRGINIA A. HodGKINSON ET AL., GIVING AND VOlunteERING IN THE UNITED STATES: Findings FROM A NATIONAL SuRVEY (1994); Virginia A. HODGKINSON ET AL., GIVING AND VOLUNTEERING IN THE UNITED STATES: FindingS FROM A NATIONAL SURVEY (1996).

34. See HodGKINSON ET AL., supra note 32, at 105 tbl. 2.19.

35. See id.

36. See id.

37. See id.

38. See id. at 28. 
total is equivalent to the work of 2.3 million full-time employees-or nine percent of total government employment. ${ }^{40}$

TABLE 1

EXTENT OF VOLUNTEERING TO GOVERNMENT

\begin{tabular}{cccc}
\hline $\begin{array}{c}\text { Pear of } \\
\text { Survey }\end{array}$ & $\begin{array}{c}\text { All Volunteers } \\
\text { Donating Time } \\
\text { to Government }\end{array}$ & $\begin{array}{c}\text { Percentage of } \\
\text { All Volunteer } \\
\text { Hours Donated } \\
\text { to Government }\end{array}$ & $\begin{array}{c}\text { Assigned } \\
\text { Dollar Value } \\
\text { (billions) }\end{array}$ \\
\hline 1992 & 26.6 & 25.3 & $\$ 55.1$ \\
1990 & 27.7 & 26.2 & $\$ 43.9$ \\
1988 & 28.9 & 22.7 & $\$ 34.0$ \\
\hline
\end{tabular}

Source: Virginia A. HodgKinSON ET AL., NONPROFIT ALMANAC, 1996-1997: DIMENSIONS OF THE INDEPENDENT SECTOR 105 tbl. 2.19 (1996).

The 1992 Gallup survey sheds some useful light on the policy areas in which volunteering to the public sector reaches its highest levels. ${ }^{41}$ Table 2 presents this information. Volunteers are most commonly involved in government through education: More than half of all reported volunteering in this field occurs in the public schools. In several other policy areas, fewer volunteers, but still more than one-third, donated time to government: international and foreign affairs, arts, culture and the humanities, adult recreation, and the environment. More than twenty percent of all volunteers in the areas of human services, health, and youth development donated time to a government organization. Because the respondent may not be fully aware of the auspices of the organization to which she or he volunteers, one must interpret these statistics with caution.

39. See id. at 29 fig. 1.3.

40. See id. at 28.

41. See id. at 105 tbl. 2.19. 
TABLE 2

MAJOR POLICY AREAS OF VOLUNTEER ACTIVITY IN GOVERNMENT

\begin{tabular}{lc}
\hline Policy Area & $\begin{array}{c}\text { Percentage of } \\
\text { Volunteers in } \\
\text { Government }\end{array}$ \\
\hline Education & 56.8 \\
International and Foreign Affairs & 38.5 \\
Arts, Culture, and the Humanities & 35.7 \\
Adult Recreation & 35.6 \\
Environment & 34.2 \\
Human Services & 24.6 \\
Health & 22.6 \\
Youth Development & 21.5 \\
\hline
\end{tabular}

Source: ViRginia A. HodgKinson ET AL., NONPROFIT ALMANAC, 1996-1997: DIMENSIONS OF THE INDEPENDENT SECTOR 105 tbl. 2.19 (1996).

As the data in Table 2 suggest, education probably attracts the largest number of people to volunteering in the public sector. In 1986, Congress commissioned a study of volunteers in public schools, which was completed four years later by the Committee on the Use of Volunteers in Schools of the National Research Council. ${ }^{42}$ The Committee found that "little is known about school-based volunteerism," ${ }^{43}$ and attempted to provide a more complete picture. The Committee examined children in kindergarten through high school and defined school or classroom volunteers as

persons who work without pay, usually under the direction of an authorized teacher or other school employee, in support of school objectives to enhance the education of students. It includes people who participate in some aspect of instruction as well as those who help with clerical or other support activities. ${ }^{44}$

The Committee found that volunteers assisted the schools in a great variety of instructional activities, such as tutoring and mentoring, career guidance, arts and crafts, art and literature appreciation, English-language skills for immigrant children, computer labs, choral, dramatic, and musical events, science fair, and school yearbooks and newspapers. ${ }^{45}$ To support the instructional mission, volunteers also assisted in libraries and media centers, helped monitor school

42. See generally VolunteERS IN PUBliC SCHOOLS (Bernard Michael ed., 1990).

43. Id. at 1.

44. Id. at 3. The Committee also recognized the role played by business-education partnerships, citizen activist organizations, advisory councils, Parent-Teacher Associations ("PTA") or ParentTeacher Organizations ("PTO"), and the like in helping to mobilize volunteers. However, membership or activities in these groups was excluded from consideration unless participants actually served as volunteers in the schools. See id. at 3-4.

45. See id. at 2 . 
lunch rooms and playgrounds, relieved teachers of paperwork and other nonacademic responsibilities, helped with field trips, and advised and supported a wide range of clubs, competitions, and athletic events. ${ }^{46}$

The Committee undertook survey research in the 1987-88 school year to help establish the magnitude of volunteering to the public schools. Prospective in nature, the survey questions asked administrators in a very large sample of 9,300 public schools to estimate how many volunteers the school expected to use during the full school year that had just begun. The questions referred specifically to volunteer services contributed on a continuing or scheduled basis, so that sporadic or informal volunteering was excluded. ${ }^{47}$ Based on the survey results, the Committee estimated that approximately one million people were expected to contribute their time to public schools in the 1987-88 school year. ${ }^{48}$ This figure is not substantially different from an estimate of 1.1 million reported in an earlier survey pertaining to the 1984-85 school year. $^{49}$ In the 1987-88 survey, approximately sixty percent of the nation's elementary and secondary public schools reported using unpaid volunteers. ${ }^{50}$ Volunteer use was greatest at the elementary level, where volunteers were found in seventy-five percent of elementary schools, with an average of about twenty-four volunteers per school. At the middle and secondary school levels, more than fifty percent of the schools reported using volunteers, with an average of about fifteen volunteers per school. $^{51}$

Unfortunately, the 1987-88 survey did not request information on the activities performed by volunteers in the schools, but the 1984-85 survey did. ${ }^{52}$ Overall, the major focus of volunteer activity reported in the earlier study was instructional support, occupying about forty-four percent of all volunteers. ${ }^{53}$ The next most reported activity, involving about twenty-eight percent of volunteers, was support with extracurricular activities, such as athletics, clubs, trips, newspapers, and libraries. ${ }^{54}$ Fourteen percent of volunteers provided management or advisory support, such as a citizen advisory group; around ten percent provided clerical support to the school; and another nine percent provided other support, such as monitoring the cafeteria or playground. ${ }^{55}$ Some five percent of volunteers assisted with guidance support, including career

\footnotetext{
46. See id.

47. See id. at 13 .

48. See id. at 16 tbl. 3-1.

49. See id. at 14 .

50. See id.

51. See id. at 15.

52. See id. at 17.

53. See id. at 17, 20 tbl. 3-3.

54. See id. at 17-19, 20 tbl. 3-3.

55. See id. at 19, 20 tbl. 3-3.
} 
counseling and health awareness. ${ }^{56}$ Because some volunteers participated in more than one activity, the percentages total more than $100 .^{57}$

The Committee on the Use of Volunteers in Schools also tried to assess the impact of school volunteering by reviewing extant literature. ${ }^{58}$ Their review uncovered significant limitations in the research on school volunteers. For example, with the exception of the voluminous research on tutoring, the Committee noted that the research is often limited by the use of small samples, perceptual measures, flawed outcome indicators, and a failure to consider volunteer program processes and administration. ${ }^{59}$ In fairness, the same critique could be applied with equal force to the research on the impact of volunteers more generally. Despite these limitations, the Committee concluded "that findings about the effects of school volunteers in the reported research were almost uniformly positive. Conversely, almost nothing indicated negative effects resulting from volunteer use in the schools." ${ }^{\circ 6}$ The research on tutoring was the most persuasive encountered, documenting student gains in both academic and nonacademic areas (for example, self-esteem, confidence, and motivation). ${ }^{61} \quad$ The review also substantiated positive effects of nontutorial volunteer activities in the classroom, such as service as teacher aides. ${ }^{62}$ The Committee found virtually no studies evaluating the considerable use of volunteers in clerical or other support activities in the schools. ${ }^{63}$

The national Gallup surveys discussed above suggest that with respect to volunteering to local, state, or federal government, local governments are the fortunate recipients of most citizen volunteer activity. ${ }^{64}$ In the 1992, 1990, and 1988 Gallup surveys, the great preponderance of volunteers to governmentbetween seventy-six and eighty-one percent-assisted local governments. State organizations were next in frequency, attracting between eleven and seventeen percent of government volunteers, and the federal government followed, with between six and nine percent of these volunteers. ${ }^{65}$

These statistics should be seen as suggestive rather than definitive, however, because public sector volunteer opportunities can cross several levels of government, much as do other policies and programs in an interdependent federal system. In all probability, the rate of volunteering to local government is exaggerated. The level of government is not always transparent to the volunteer or to the survey respondent. For example, the U.S. Department of

56. See id.

57. See id. at 20 tbl. 3-3. The category of "management or advisory support" reported in the 198485 survey would seem to contradict the definition of school volunteers used by the Committee; however, the report does not present sufficient detail regarding the survey to make this determination.

58. See id. at 31-43.

59. See id. at 40.

60. Id.

61. See id. at 32 .

62. See id. at 34-35.

63. See id. at 41.

64. See HodGKInSON ET AL., supra note 32, at 105 tbl. 2.19.

65. See id. 
Agriculture's Cooperative Extension System, which attracts huge numbers of volunteers as shown below, is a complex network of federal, state, and local organizations, often including school districts and universities. Similarly, the U.S. Department of Health and Human Services, also a major employer of volunteer labor, distributes funding for its Older Americans programs to the states, which in turn apportion the funds to local area offices to administer. Based on a study of volunteers to the federal government, Gary Pergl advises, "The relationships between federal agencies and their volunteers are as varied as the work the volunteers do. Sometimes volunteers work directly with the agency. Other times they work for federally sponsored programs administered by the states, or they volunteer for organizations that assist the federal government ...." ${ }^{66}$ From their perspective, most citizens donate their time to have a local impact. When they volunteer to a local office of a federal agency, many, if not most, likely identify more strongly with their local community than with a distant, national headquarters in Washington, D.C. To complicate matters further, the Gallup surveys do not probe for detailed information concerning the level of government sponsoring the volunteer opportunity.

Nevertheless, given the preponderance of volunteering reported in the Gallup surveys, most of this assistance likely occurs in local government. To assess the magnitude and scope of volunteer activity, the National Association of Counties ("NACo") has conducted surveys of county governments. A preliminary study was carried out in 1985, and more recent studies were conducted in 1993 and 1996. These surveys found a very high incidence of volunteering, defined as involving "volunteers in government operations (including advisory boards, firefighters, and other direct service roles)." 1985 NACo study reported that in 133 of the 135 government services examined volunteers assisted in at least one county. ${ }^{68}$ In the 1993 survey, ninety-three percent of responding counties reported utilizing volunteers; in the 1996 survey, this figure increased to ninety-eight percent. ${ }^{69}$ Moreover, approximately one in five responding counties reported that they use more than 500 volunteers per year in government operations. ${ }^{70}$ The authors of the 1996 NACo study concluded that "[v]olunteerism in county government is on the rise."

Other studies reinforce this assessment of high volunteer involvement in public-service delivery at the local level. ${ }^{72}$ Based on a survey conducted in 1985, Sydney Duncombe estimated that $72.6 \%$ of cities with more than 4,500

66. Gary Pergl, Volunteers for Government, 23 GOV'T EXEC. 26, 28 (Feb. 1991).

67. Peter Lane \& Cynthia Shultz, Volunteerism in County Government Survey RESUlts 5 \& tbl. 2 (National Association of Counties Apr. 1996).

68. See national Association of Counties, The Volunteer ToOlbox: Visions for IMPROVING THE SERVICE OF AMERICA's COUNTIES 4 (1990).

69. See LANE \& SHULTZ, supra note 67 , at 1.

70. See id at 3.

71. See Peter Lane \& Cynthia Shultz, An Overview of Volunteerism in County Government, 15 J. VOLUNTEER ADMIN. 5 (Winter 1997) (emphasis omitted).

72. See BRUDNEY, supra note 8 , at $10-11$. 
residents employed volunteers in at least one service domain. ${ }^{73}$ He reported that volunteers assisted cities in more than sixty types of jobs, most frequently as firefighters, recreation staff, police auxiliaries, senior citizen center assistants, library aides, and park maintenance workers. ${ }^{74}$ Duncombe's survey established that utilization of volunteer personnel by city governments was quite robust: Volunteer use rose with city size, reaching $100 \%$ in cities with populations greater than 200,000. In addition, at least half of all responding cities within each category of geographic region, population size, and government type (for example, council-manager and mayor-council) used volunteers. ${ }^{75}$ Consistent with these results, a survey conducted at about the same time in 1988 by the International City/County Management Association ("ICMA") on the use of alternative service-delivery approaches found that contracting and using volunteers by local governments "seem well entrenched as service delivery mechanisms across a wide range of services." " The study forecasted that "it seems reasonable to expect their continuation or potential growth in the future." $" 77$

The NACo surveys show that volunteers help provide services in a wide range of policy domains. According to the 1996 survey results shown in Table 3 , about fifty percent or more counties use volunteers in firefighting and emergency medical services, aging, libraries, parks and recreation, and youth services. About forty percent engage them in social services, education, environment/recycling, sheriff/corrections, and community and economic development, and about one-third of the counties reportedly use volunteers in public safety and public health. ${ }^{78}$

73. Sydney Duncombe, Volunteers in City Government: Advantages, Disadvantages and Uses, 74 NAT'L CIVIC REVIEW 358-59 (1985).

74. See id. at 360.

75. See id. at 359.

76. See Elaine Morley, Patterns in the Use of Alternative Service Delivery Approaches, in MUNICIPAL YEAR BOOK 33, 44 (1989).

77. $I d$.

78. LANE \& ShUlTZ, supra note 67 , at 5 tbl. 3. The survey item focused on service delivery and specifically excluded volunteer activity on "boards and commissions." 
TABLE 3

VOLUNTEER INVOLVEMENT IN COUNTY GOVERNMENTS: POLICY AREAS

\begin{tabular}{lc}
\hline Policy Area & $\begin{array}{c}\text { Percentage of } \\
\text { County Governments } \\
\text { Using Volunteers }\end{array}$ \\
\hline Firefighting/Emergency Medical Services & 72.7 \\
Aging & 63.7 \\
Libraries & 50.2 \\
Parks and Recreation & 49.0 \\
Youth Services & 48.0 \\
Social Services & 42.5 \\
Education & 42.4 \\
Environment/Recycling & 40.9 \\
Sheriff/Corrections & 40.0 \\
Community and Economic Development & 37.3 \\
Public Safety & 34.7 \\
Public Health & 33.1 \\
\hline
\end{tabular}

Source: Peter LANe \& CYNTHIa Shultz, VolunteERISM In COUNTY GOVERNMENT SURVEY RESULTS 5 (1996).

The 1988 ICMA survey also documents the involvement of volunteers in local government in a variety of service domains. ${ }^{79}$ As Table 4 illustrates, more than one-third of the sample of cities and counties used volunteers in culture and the arts, food programs, and museum operations, and one-fourth involved volunteers in recreation, homeless shelters, and programs for the elderly. At least ten percent of the cities and counties used volunteers in fire prevention and suppression, emergency medical service, ambulance service, crime prevention/patrol, libraries, child welfare, and drug/alcohol treatment. ${ }^{80}$

79. See Morley, supra note 76 , at 40 tbl. $4 / 13$.

80. See id. The ICMA surveys do not include public education. As shown in the discussion above, education is a service area that has widespread use of volunteers. 
TABLE 4

VOLUNTEER INVOLVEMENT IN CITY AND COUNTY GOVERNMENTS: POLICY AREAS

\begin{tabular}{lc}
\hline Policy Area & $\begin{array}{c}\text { Percentage of City and } \\
\text { County Governments } \\
\text { Using Volunteers }\end{array}$ \\
\hline Culture and the Arts & 41 \\
Food Programs & 37 \\
Museum Operations & 34 \\
Recreation & 26 \\
Homeless Shelters & 26 \\
Programs for the Elderly & 25 \\
Fire Prevention and Suppression & 19 \\
Emergency Medical Service & 18 \\
Ambulance Service & 17 \\
Crime Prevention/Patrol & 16 \\
Libraries & 13 \\
Child Welfare & 11 \\
Drug/Alcohol Treatment & 10 \\
\hline
\end{tabular}

Source: Elaine Morley, Patterns in the Use of Alternative Service Delivery Approaches, in MuniCIPAL YEAR BOOK, 1989, at 40 tbl. 4/13 (1989).

Despite the high incidence of volunteer use reported in these studies, surveys conducted by the ICMA in the 1990s have failed to substantiate the forecast of even greater volunteer involvement in local government made in the 1988 ICMA study. ${ }^{81}$ A 1992 ICMA survey on service-delivery approaches reported marked declines in the use of volunteers by local governments since the 1988 survey. ${ }^{82}$ According to a follow-up survey conducted in 1997, these trends had mostly stabilized by the mid-1990s, yet, as measured by the ICMA, "there were some fairly substantial decreases in the use of volunteers between 1988 and 1997."

The ICMA results conflict with the surveys conducted by NACo, which indicate much more robust and increased use of volunteers during the 1990s. The ICMA results also contradict the increasing publicity and attention given to

81. See id. at 44 .

82. Rowan Miranda \& Karlyn Andersen, Alternative Service Delivery in Local Government, 19821992, in MUNICIPAL YEAR BOOK, 1994, at 28, 33 (1994).

83. Elaine Morley, Local Government Use of Alternative Service Delivery Approaches, in MUNICIPAL YEAR BOOK 40 (1999). 
volunteer involvement in all aspects of society, including government. The ICMA acknowledges that some of the variations over time may be attributable to differences in the jurisdictions that responded to their surveys or may result from self-selection bias in the sample of respondents. In addition,

[i]t may be that the use of volunteers was not fully reported in the ICMA survey, perhaps because volunteers may be used by the for-profit and nonprofit firms with which local governments contract for services rather than by the governments themselves. In such cases, officials responding to the survey may report the use of contracting rather than the use of volunteers. ${ }^{84}$

Although it is not clear why this problem may have surfaced only in the 1997 survey, by comparison to other studies, the ICMA surveys may have underestimated the magnitude of volunteer participation in service delivery by local governments.

Perhaps because most volunteering to government apparently occurs at the local level, survey research has focused primarily on volunteer use by cities and counties. Unfortunately, much less systematic data on volunteer involvement are available for the state and the federal governments.

Based on a nationwide survey of personnel managers in state agencies, J. Edward Kellough and I found that state governments use volunteers to assist in many of the same policy domains as do other governments. ${ }^{85}$ In our sample, agencies with missions related to environmental protection, health, hospitals, natural resources, parks and recreation, and public welfare were most likely to have volunteers. ${ }^{86}$ In addition to these domains, a study of state service delivery by the Council of State Governments explored other areas in which the states make use of volunteer personnel, including human services, corrections, education, and tourism. ${ }^{87}$ At least sixty percent of state parks use volunteers, primarily to offer visitor services, such as providing information, collecting fees, and performing minor maintenance, ${ }^{88}$ but also to plant trees and shrubs, construct and maintain trails and shelters, and control erosion. ${ }^{89}$ Although the level of volunteer involvement in state governments appears to be much less than in local governments, the amount is considerable nevertheless. From the results of our survey, Kellough and I estimate that thirty-six percent of state agencies enlist volunteers in delivering services. ${ }^{90}$

In the federal government, the agencies best known for enlisting citizen participants sponsor comparatively small, stipended volunteer programs-

84. $I d$.

85. Jeffrey L. Brudney \& J. Edward Kellough, Volunteers in State Government: Involvement, Management, and Benefits, 29 NONPROFIT \& VOLUNTARY SECTOR Q. 111, 117, 118 tbl. 1 (2000).

86. See id. at 118 tbl. 1.

87. See generally JoAn W. Allen ET Al., The Private Sector in State Service Delivery:

EXAMPLES OF INNOVATIVE PRACTICES (1989).

88. See id. at $55-56$.

89. See id. at 56.

90. See Brudney \& Kellough, supra note 85, at 117. 
Peace Corps and AmeriCorps-VISTA. ${ }^{91}$ With respect to volunteer involvement, these programs are the exception, rather than the norm. Substantially more volunteers assist other federal agencies directly in the delivery of services. The most spectacular example is the Cooperative Extension Service ("CES") of the U.S. Department of Agriculture, which sponsors the 4-H program, home economics programs, horticulture and agriculture programs, and local resource development activities. A comprehensive 1984 evaluation estimated that in 1983, 2.9 million people worked with CES as volunteers, compared to the 11,200 county agents employed by CES. ${ }^{92}$ The aggregate amount of time donated by volunteers to CES surpassed seventy-one million days, a sum almost fifty-one times larger than the total time worked by the relatively small paid staff. $^{93}$ The monetary value of donated services exceeded $\$ 4.5$ billion, an amount five times greater than the total CES budget for the year- $\$ 860$ million. ${ }^{94}$ The Cooperative Extension Service is engaged in community development, and volunteers seem to be involved in every facet, including disseminating information about agriculture, business, youth development, and survival skills $;{ }^{95}$ assisting in special projects and events such as community fairs, livestock shows, nature conservatories, crime watch, and disaster relief $;{ }^{96}$ and supporting local organizations through fund-raising, board membership, planning activities, community surveys, outreach, and technical assistance. ${ }^{97}$

Although they cannot equal the magnitude of volunteer involvement in the Cooperative Extension Service, several other federal departments and agencies sponsor sizable volunteer programs. A review by Pergl of many of these programs reveals the scope and breadth of these activities. ${ }^{98}$ Large numbers of volunteers work with the federal government in the area of the environment. The U.S. Forest Service of the Department of Agriculture staffs about 67,000 volunteers who work on trail construction and maintenance, fish and wildlife management, research projects, and visitors programs. Many other volunteers work for the Soil Conservation Service. In the U.S. Department of the Interior, the National Park Service has about 54,000 volunteers working in most national parks, monuments, and historic sites. The volunteers staff visitor centers, guide tours, repair trials, conduct research, and drive shuttle busses. The Interior Department's Bureau of Land Management and the Fish and Wildlife Service

91. These two programs have been merged. Because citizens receive a stipend for their participation in these organizations, they lie outside the definition of volunteer used in this article and will not be considered further.

92. UNIVERSITY OF WISCONSIN-MADISON DEPARTMENT OF CONTINUING AND VOCATIONAL EDUCATION, PARTNERS IN ACTION: COUMMUNITY VOLUNTEERS AND COOPERATIVE EXTENSION Agents: NATional Projections 3 (Nov. 1984).

93. See id. at 1.

94. See id. at 4.

95. See id. at 7.

96. See id. at 8 .

97. See id. at 8-9.

98. See generally Pergl, supra note 66. Unless otherwise noted, all estimates of the size of the volunteer corps in various federal agencies found in this section are from this source. 
together employ another 23,000 volunteers, and the U.S. Geological Survey and the Bureau of Indian Affairs employ about 800 volunteers between them. In 1989, the Department of the Interior had more volunteers-77,000-than paid employees-72,000. Table 5 presents the numerical estimates of volunteers at the different federal agencies. ${ }^{99}$

TABLE 5

VOLUNTEER INVOLVEMENT IN FEDERAL AGENCIES

\begin{tabular}{lc}
\hline Federal Agency & $\begin{array}{c}\text { Estimated Number } \\
\text { of Volunteers }\end{array}$ \\
\hline $\begin{array}{l}\text { Cooperative Extension Service, } \\
\quad \text { Department of Agriculture }\end{array}$ & $2,900,000$ \\
Head Start, & 600,000 \\
$\quad$ Department of Health and Human Services & 450,000 \\
Older Americans Programs, & \\
$\quad$ Department of Health and Human Services & 87,000 \\
Department of Veterans Affairs & 67,000 \\
U.S. Forest Service, Department of Agriculture & 53,600 \\
National Park Service, Department of the Interior & 23,000 \\
Bureau of Land Management and Fish & and Wildlife Service, Department of the Interior \\
$\quad$ Service Corps of Retired Executives (SCORE), & 13,000 \\
$\quad$ U.S. Small Business Administration & 10,000 \\
National Oceanic and Atmospheric Administration & 2,100 \\
Bureau of Prisons & 800 \\
U.S. Geological Survey and Bureau of Indian Affairs &
\end{tabular}

Sources: JefFrey L. Brudney, Fostering VolunteER Programs IN THE Public Sector: PlanNing, INITIATING, AND MANAGING VOluntary ACTIVITIES 79 (1990); UNIVERSiTy OF WISCONSIN-MADISON DEPARTMENT OF CONTINUING AND VOCATIONAL EDUCATION, PARTNERS IN ACTION: COMMUNITY VOLUNTEERS AND COOPERATIVE EXTENSION AGENTS: NAtional Projections 1 (Nov. 1984); Gary Pergl, Volunteers for Government, 23 Gov'T EXECUTIVE 28, 30 (Feb. 1991).

The U.S. Department of Health and Human Services ("HHS") is another major user of volunteer services. HHS administers the Older Americans Act of 1965, which provides for nutritional and other assistance to the elderly, as well

99. As impressive as these (and other) statistics pertaining to volunteer involvement in federal government agencies may be, information is not available regarding the full-time equivalent employment generated by the volunteers. 
as home visitation and transportation. ${ }^{100}$ The agency relies heavily on the assistance of volunteers. More than 350,000 volunteers help prepare, serve, and deliver meals to senior citizens in senior centers and through home delivery. Another 100,000 volunteers make home visits, provide recreational services to seniors, and accompany elderly recipients on shopping trips and doctor visits. ${ }^{101}$ HHS also uses volunteers to work with children in the Head Start program. More than 600,000 volunteers-most of them parents of Head Start Childrenserve as teachers, classroom aides, food preparers, health assistants, and recreation specialists. ${ }^{102}$ In all, HHS enlists about one million volunteers.

Pergl notes a few other volunteer programs sponsored by the federal government. The U.S. Department of Veterans Affairs lists more than 160 different job areas for its 87,000 volunteers, such as visiting and assisting patients in Veteran Affairs hospitals and nursing homes. ${ }^{103}$ The U.S. National Oceanic and Atmospheric Administration has 10,000 volunteer weather observers who donate more than one million hours a year making daily records of the weather across the U.S. ${ }^{104}$ Some 2,100 people volunteer to the nation's sixty federal prisons. They lead regular weekly worship services and study groups, conduct special seminars and reflective programs, counsel prisoners, and provide entertainment. ${ }^{105}$ In addition to the volunteer programs described by Pergl, the U.S. Small Business Administration ("SBA") sponsors the Service Corps of Retired Executives ("SCORE") program, an association numbering about 13,000 volunteers-three to four times the number of paid SBA employees-who provide business management assistance to aspiring and established entrepreneurs. ${ }^{106}$ The Internal Revenue Service of the U.S. Department of the Treasury sponsors the Tax Counseling for the Elderly ("TCE") and Volunteer Income Tax Assistance ("VITA") programs to help citizens prepare their tax returns. ${ }^{107}$ Additional federal agencies in which volunteers are directly involved in the delivery of services include the Department of Housing and Urban Development, Department of Justice, Department of Transportation, Environmental Protection Agency, Army Corps of Engineers, and the National Library Service. ${ }^{108}$ In sum, although most volunteers and volunteer labor serve the nonprofit sector, a surprisingly large

100. See Pergl, supra note 66, at 30.

101. See id.

102. Pergl gives no indication that these volunteers-or any others discussed in his article-receive payment. See id.

103. See id.

104. See id. at 28.

105. See id.

106. See BRUDNEY, supra note 8 , at 79 .

107. See id. at 5-6.

108. See id.; see also Jeffrey L. Brudney \& Nancy Macduff, A Cynical Public Loves Its Government: An Overview of Government Volunteers and People Who Manage Them, Presented at the Annual Conference of the Association for Research on Nonprofit Organizations and Voluntary Action 7-9 (Dec. 4-6, 1997) (on file with author). 
number of citizens contribute their time to assist governments at all levels in the United States across a wide variety of service domains.

IV

\section{BEST PRACTICES FOR VOLUNTEER PROGRAMS}

Much of the practitioner literature advances many recommendations to develop and sustain a thriving volunteer program in nonprofit and government organizations. Although this literature is richly informed by the experiences of the authors in consultation and training, it offers no empirical verification for incorporating the recommended characteristics and features. For their part, academic researchers have done little to establish the frequency with which these recommended "best practices" are used in volunteer programs, or to examine systematically their possible connection to program effectiveness. The analysis presented below is intended to initiate this inquiry. It assesses the application of a lengthy list of purported best practices in a large sample of government-based volunteer programs and explores the relationship between each of them and the benefits realized from volunteer involvement, as perceived by the managers of these programs. ${ }^{109}$

To begin, the first recommended best practice is to gain support from highlevel officials for the volunteer program. Indeed, this admonition is the premise of a leading text in volunteer administration, From the Top Down: The Executive Role in Volunteer Program Success. ${ }^{110}$ In it, Susan J. Ellis makes a strong case that these programs must have a manager, often referred to as a "coordinator" or "director" of volunteers or of volunteer services. According to Ellis, a successful volunteer program requires that a large proportion of this official's work time be dedicated to managing and working with the volunteers. ${ }^{111}$ Such admonitions notwithstanding, empirical research has demonstrated that most coordinators of volunteers have major additional work responsibilities that limit the time they can devote to the volunteer program. ${ }^{112}$

To facilitate the task of volunteer program management-and to allay the apprehensions of employees and volunteers alike regarding the involvement of lay citizens and the rights and responsibilities of each party-experts agree that

109. The recommended "best practices" in volunteer administration are taken from major texts in the field. See generally SUSAN J. ElLIS, FROM THE TOP DOWN: THE EXECUTIVE ROLE IN Volunteer Program Success (revised ed. 1996); JAMES C. Fisher \& KATHLEEN M. Cole, LEADERSHIP AND MANAGEMENT OF VOLUNTEER PROgRAMS: A GuIDE FOR VOlunTEeR ADMinistrators (1993); STEVE MCCURLEY \& RICK LYNCH, VOlunteER MANAGEMENT: MOBILIZING ALl THE ResourCES IN THE COMMUNITY (1996); THE VOLUNTEER MANAGEMENT HANDBOOK, supra note 22.

110. See generally ELLIS, supra note 109. Ellis goes so far as to provide an "Executive Role Checklist" at the conclusion of her volume to reinforce the necessity of securing high-level support to create and maintain a successful volunteer program. See id. at 181-93.

111. See id. at 51-52.

112. See BRUDNEY, supra note 8, at 79-80; Jeffrey L. Brudney et al., The Association for Volunteer Administration and Professionalization of the Field: Suggestions from a Survey of the Membership, $12 \mathrm{~J}$. VOLUNTEER ADMIN. 1, 3 (Fall/Winter 1993-94). 
the organization must provide written policies to govern the volunteer program: ${ }^{113}$ "The policies will allow the [v]olunteer [p]rogram [m]anager to develop a consistent pattern of volunteer involvement, and will provide assistance in dealing with problem situations." ${ }^{114}$

Another highly recommended best practice is to create job descriptions for volunteer positions. Unless and until an organization has determined why volunteers are needed and the specific jobs they will be asked to perform, recruitment, training, management, and evaluation of unpaid workers are nearly hopeless tasks. ${ }^{115}$ "In the volunteer management profession, there is universal agreement that volunteers deserve written job descriptions. Such descriptions clarify roles and differentiate what volunteers do from what employees do." $" 116$

With written job descriptions available, it becomes possible to target and recruit volunteers to fill specific positions. Still, recruitment is widely acknowledged as the most difficult of all tasks in volunteer administration. ${ }^{117}$ Accordingly, organizations should practice active outreach to recruit volunteers. ${ }^{118}$

Once volunteers have been brought on-board, host organizations should provide necessary support activities. These activities start with an orientation for all new volunteers, regardless of their specific work assignments. ${ }^{119}$ Orientation consists of a short, general learning program designed to provide an overview of the organization and its mission and to expose the volunteers to the organization's culture and method of operations. ${ }^{120}$ Because volunteers typically come to the organization with highly variable backgrounds, experiences, knowledge, and preparation in the policy or service domain of the agency, training and development for citizen volunteers are important parts of volunteer administration. ${ }^{121}$ For example, James C. Fisher and Kathleen M. Cole title their chapter on volunteer training and development "Keys to Effectiveness." ${ }^{122}$ They recommend that organizations provide basic training, that is, specific preparation for the jobs to be held by volunteers, including the skills, knowledge, and procedures required. ${ }^{123}$ In addition, experts endorse ongoing or in-service training for volunteers: "Training is an ongoing part of participation in an organization and it is imperative that in-service training be

113. For an excellent discussion of this topic, see Linda L. Graff, Policies for Volunteer Programs, in THE VOLUNTEER MANAGEMENT HANDBOOK, supra note 22, at 125.

114. MCCURLEY \& LYNCH, supra note 109, at 23.

115. See ELLIS, supra note 109, at 88.

116. Id.; see also FISHER \& COLE, supra note 109, at 72-73.

117. See BRUDNEY, supra note 8, at 153 .

118. See id.

119. See ELLIS, supra note 109, at 185 .

120. See, e.g., FISHER \& COLE, supra note 109, at 100-01.

121. See id. at 97.

122. Id.

123. See id. at 102-03. 
provided ...." ${ }^{124}$ This best practice is thought to alleviate potential problems of volunteer boredom, burn-out, and turnover that might otherwise occur were the organization to continue to treat experienced volunteers as if they were still new to the organization. ${ }^{125}$

A closely related best practice to reinvigorate senior volunteers is to empower volunteers to manage other volunteers. Fisher and Cole advocate "career ladders" for volunteers as a creative way for host organizations to respond to changes in the motivations, needs, expectations, and abilities of volunteers as their experience in the organization lengthens. ${ }^{126}$ With greater experience should come increased responsibility for volunteers. ${ }^{127}$ "[V]olunteers make excellent mid-level supervisors of other volunteers... . Such administrative volunteers can be project coordinators for specific activities, orient groups of new volunteers, or follow-up on work being done by other volunteers off-site." "[V] 128 olunteers can also be trained to supervise each other... . Creating such leadership roles within the volunteer corps demonstrates that volunteer experience is valued and trusted." ${ }^{129}$ In his study of the volunteer SCORE program sponsored by the U.S. Small Business Administration, for example, Brudney found that SCORE chapters around the country were virtually self-managing, with senior volunteers occupying formal leadership positions to supervise and manage the other volunteers. ${ }^{130}$

Additional organizational support services include recognition activities for volunteers, widely regarded as fundamental to an effective volunteer program. "Volunteers must receive a sense of appreciation and reward for their contribution. This sense can be conveyed through a number of processes, including both formal and informal recognition systems." ${ }^{131}$

Another recommended best practice is the evaluation of volunteers. However, evaluation is more problematic because it carries connotations of "being judged" and seems to question the value of the volunteer's "gift" or donation of time. "Evaluations of volunteers, if done well, can be a very insightful tool for the volunteer, the supervisor, and the volunteer manager. However, it is commonly the area that continually gets neglected for both paid employees and volunteer staff." 132 Evaluation of volunteers presupposes that accurate information exists regarding their participation in the organization. Hence, organizations should keep formal records for volunteers, including such

124. Arlene Stepputat, Administration of Volunteer Programs, in THE VolunTEER MANAGEMENT

HANDBOOK, supra note 22, at 156, 174. Ellis shares this view. See Ellis, supra note 109, at 185.

125. See FISHER \& COLE, supra note 109, at 64-66, 74-76.

126. See id. at 85 .

127. See id. at 65-66, 75-76.

128. ELLIS, supra note 109 , at 66.

129. Stepputat, supra note 124 , at 177.

130. See BRUDNEY, supra note 8, at 114.

131. MCCURLEY \& LYNCH, supra note 109, at 122.

132. Stepputat, supra note 124 , at 177. 
information as the number of hours contributed. ${ }^{133}$ This recommendation, too, seems to provoke resistance, in this case from the volunteers: "One of the objections often raised about keeping track of volunteer hours is that it is difficult, if not impossible, to get volunteers in all categories to keep a record of the time they contribute." ${ }^{134}$

Training and development are recommended for employees who work with volunteers. ${ }^{135}$ In fact, training for employees may be more crucial because formal education in volunteer involvement or administration is not a standard part of the education of most organization members, including mid-level managers ${ }^{136}$ - even those who possess an advanced academic degree or concentration in nonprofit sector studies, much less those with a focus on the public sector. ${ }^{137}$

A volunteer program cannot be expected to accomplish its goals unless resources are allocated to it; therefore, the organization must provide a budget for the volunteer program. ${ }^{138}$ Among the items the budget should contain is reimbursement for the volunteers' work-related expenses. These "enabling funds," as Ellis refers to them, allow people from all economic and social strata to give their services freely. ${ }^{139}$

The concept of enabling funds has grown in acceptance in the field of volunteerism and stems from the desire to diversify the corps of volunteers as much as possible. If consideration is not given to out-of-pocket costs, then too many programs will have as volunteers only those people who can afford the 'luxury' of volunteering. ${ }^{140}$

Another item that should be budgeted is a newsletter for volunteers, an inexpensive, yet potentially effective method to inform volunteer workers about organizational policies, events, and changes; to provide training and recognition; and to build commitment and cohesion among the volunteer cohort. ${ }^{141}$

Finally, organizations should provide liability insurance coverage for volunteers. Employment law regarding volunteer labor is complicated and contentious. Legal experts concur that organizations should purchase liability

133. The full item stated: "formal record-keeping for volunteers, such as the number of hours contributed."

134. ELLIS, supra note 109, at 162-63.

135. See id. at 90-91; FISHER \& COLE, supra note 109, at 121-23.

136. See BRUDNEY, supra note 8, at 109; ELLIS, supra note 109, at 90.

137. Research shows that even in educational programs concentrating on the nonprofit sector, coverage of volunteer administration and management is rare. See Jeffrey L. Brudney \& Gretchen E. Stringer, Higher Education in Volunteer Administration: Exploring-and Critiquing-the State of the Art, in NonProfit Management Education: U.S. AND WORLD PERSPECTIVES 95, 103-05 (Michael O’Neill \& Kathleen Fletcher eds., 1998).

138. See ELLIS, supra note 109, at 35. For details on preparation of the budget for the volunteer program, see $i d$. at 35-50.

139. See id. at 42.

140. Id.

141. See Susan J. Ellis, The VolunteEr Recruitment (AND MEMBERShip DeVElopment) BоOK 65-66 (1996). 
insurance to underwrite the reasonable risks associated with volunteer involvement. ${ }^{142}$

Based on this review of the literature in volunteer administration, the analysis below examines the frequency with which seventeen best practices are applied in a sample of government-based volunteer programs. The analysis also presents tentative evidence regarding the relationship between these best practices and the achievement of program benefits from the volunteers, as perceived by the volunteer coordinators. The following section discusses the sample of volunteer programs and the methodology of the analysis.

\section{$\mathrm{V}$ \\ DATA AND METHODS}

Only a handful of studies have examined the characteristics and practices of government-based volunteer programs or how these design and management features might affect program performance. ${ }^{143}$ A primary obstacle to conducting such a study is the lack of a systematic sample of government organizations that use volunteers to assist in the delivery of services. No enumeration of volunteer programs exists for the public sector. ${ }^{144}$ Several factors compound the difficulty of locating these programs and obtaining data regarding their operations.

First, across government organizations, the volunteer program may be found in different units, sections, or departments, or at different levels of the organizational hierarchy. Second, the unit may not include the term "volunteer" in its title (for example, Department of Public Relations or Department of Community Services or Affairs). Third, in large, complex agencies or government jurisdictions, some, or perhaps most, officials may not be aware that the organization enlists unpaid volunteers in a particular unit or may not know where the program is housed. The administrators of these programs work in a wide array of organizations, units, and jobs. ${ }^{145}$ Typically, they have important duties in addition to volunteer management so that their formal job titles can mask the connection to volunteers (for example, personnel administrator, human resources manager, or community development specialist), thus making it more difficult for a researcher to locate these programs and contact the program administrator. ${ }^{146}$

To begin to assess the state of volunteer-management practices in the public sector, in 1997, Nancy Macduff and I undertook a marketing study to identify government agencies with volunteers and to survey a sizable sample of these

142. See id. at 148; MCCURLEY \& LYNCH, supra note 109, at 143-48; Eide, supra note 22, at 359; Katharine S. Vargo, Risk Management Strategies, in THE VolunTEER MANAGEMENT HANDBooK, supra note 22, at $322,327$.

143. See generally Brudney \& Kellough, supra note 85; Jeffrey L. Brudney, Volunteers in the Delivery of Public Services: Magnitude, Scope, and Management, in HANDBOOK OF PUBLIC PERSONNEL ADMINISTRATION 661 (Jack Rabin et al. eds., 1995); BRUDNEY, supra note 8.

144. Enumeration of volunteer programs does not exist for the nonprofit sector either.

145. See Brudney \& Stringer, supra note 137, at 95.

146. See id. 
programs. ${ }^{147}$ Using our professional contacts to obtain listings of volunteer programs known to be housed in some agencies and at different levels of government, a team of researchers telephoned agencies likely to have volunteer programs. ${ }^{148}$ In all, the marketing effort succeeded in locating 4,800 volunteer programs across government agencies with an identified staff person as program manager. The sample size was limited because of the time and funding that could be allocated to the project, and not because the researchers had any difficulty locating volunteer programs sponsored by government. ${ }^{149}$

From this extensive listing of government-based volunteer programs, the researchers selected a random sample of 500 programs for a mail survey in July through September 1997..$^{150}$ A total of 188 useable questionnaires were received from this group, yielding a response rate of $39.6 \%$. These data provide the basis for the empirical analysis below concerning best practices in government-based volunteer programs.

Table 6 shows the composition of the sample by level of governmentfederal, state, or local-sponsoring the volunteer program. A bias exists in the sample toward federally based programs- $43.5 \%$ of the sample-especially in light of data presented earlier illustrating that local government is likely the largest user of volunteer labor. Local (city or county) volunteer programs account for $26.6 \%$ of the sample, the second highest proportion, but well below the representation of the federal programs. As argued above, the Gallup surveys almost certainly overestimate the extent of volunteering at the local level. ${ }^{151}$ Studies conducted by the IMCA, for example, report declines in volunteering to city and county governments in the $1990 \mathrm{~s}^{152}$ Nevertheless, the bias in the sample should be considered when interpreting the findings.

147. See generally Brudney \& Macduff, supra note 108 .

148. See id. at 8.

149. See id. at 9.

150. See id. at 10. The effective sample size turned out to be slightly smaller, consisting of 475 names. Twenty-five names were eliminated from the sample for various reasons. First the U.S. Postal Service returned ten surveys as "undeliverable as addressed." Second, the survey cover letter specified that the questionnaire pertained to government-based volunteer programs, but five respondents reported that their organizations were a private, nonprofit organizations. Third, five questionnaires were returned with annotations stating that the organization does not have a volunteer program or does not use volunteers. Fourth, four recipients indicated that the position of volunteer director or coordinator was vacant; one reported that it had been eliminated. Finally, one blank questionnaire was returned without written comment. See id. at 12 tbl. 1 . Additional members of the sample could have had the same or similar problems, but these were the only problematic surveys returned to the researchers. Excluding these recipients decreases the potential sample to its effective size of 475 coordinators of government-based volunteer programs. For a complete discussion of the survey methodology, see id. at 10-13. The surveys were addressed and mailed with postage-paid response envelopes to the government volunteer coordinator/manager. The cover letter contained the instruction that if the recipient was not the person who directly manages volunteers in the agency, to forward the questionnaire to the individual with that responsibility.

151. See Morley, supra note 76, at 44.

152. See Miranda \& Andersen, supra note 82, at 33. 
TABLE 6

COMPOSITION OF SAMPLE OF GOVERNMENT-BASED VOLUNTEER PROGRAMS

\begin{tabular}{lc}
\hline Level of Government & $\begin{array}{c}\text { Percentage of } \\
\text { Programs }\end{array}$ \\
\hline Federal & 43.5 \\
State & 16.3 \\
Local & 26.6 \\
Combination (multiple levels) & 13.6 \\
\cline { 2 - 2 } & 100.0 \\
& $(\mathrm{~N}=184)$ \\
\hline
\end{tabular}

Table 6 also lists "combination" programs, that is, volunteer programs sponsored and administered by more than one level of government. In completing the questionnaire, $13.6 \%$ of the sample indicated that their volunteer program spanned different levels of government. These respondents were primarily from the U.S. Department of Agriculture's Cooperative Extension System, which includes the 4-H program. As discussed in the previous section, CES is a highly complex federal-state-local service network. ${ }^{153}$

The federally based volunteer programs in the sample include those sponsored by the Army Corps of Engineers, Bureau of Prisons, Forest Service, Internal Revenue Service, National Park Service, Small Business Administration, and Veterans Administration. In part, the composition of the sample demonstrates that it was easier for the research team to identify and contact a single national agency to obtain a mailing list of its volunteer program coordinators than to locate myriad state and local agencies and contact them individually for the same purpose. To attempt to compensate for this bias, the researchers contacted professional associations in policy areas known to have substantial volunteer involvement, in particular, education, libraries, firefighting, culture and the arts, and blind and physically handicapped. The state and local government volunteer programs in the sample were primarily from these service domains.

This sample cannot be said to be representative of the population of government-based volunteer programs or program managers-the parameters of that population are not very well known or understood. Nevertheless, the sample is large and varied, especially for a field of study in which most research is case-study or small-sample. It includes volunteer programs found at all levels of government, spanning forty-six states, the District of Columbia, and Puerto Rico. These programs operate in a very broad mix of government

153. See supra notes $92-97$ and accompanying text. 
organizations, jurisdictions, and policy areas, including the environment, conservation, education, literacy, library, youth development, museums and cultural institutions, agriculture, community development, veterans' affairs, blind and physically handicapped, prisons, firefighting, tax preparation, small business, and general government operations.

\section{VI}

\section{FINDINGS}

The first goal of the analysis was to examine how frequently the government-based volunteer programs in the sample adopted the best practices recommended in the literature about volunteer administration. The survey questionnaire asked the sample of volunteer coordinators to indicate whether each of sixteen program characteristics had been applied to their volunteer program. Table 7 lists the items as they appeared on the questionnaire, with the associated frequency of use across the sample of government-based volunteer programs. $^{154}$

In this sample, the characteristic implemented most often was recognition activities for volunteers, used by more than ninety percent of the governmentbased volunteer programs, according to the sample of program coordinators. Next in reported frequency is formal record-keeping for volunteers, at $79.8 \%$. This finding is both encouraging and a bit surprising. Although careful recordkeeping is crucial in public organizations, it is not an activity that volunteers normally relish, nor does it rank high in their value systems for donating time. ${ }^{155}$ Nevertheless, this best practice has apparently achieved wide application across the sample of government-based volunteer programs.

Nearly eighty percent of the programs have written policies governing the program. An intriguing aspect of this finding is that while government organizations are often criticized for excessive reliance on rules, procedures, and policies, slightly more than one in five of the volunteer programs surveyed reportedly operate without written policies for their volunteers.

154. The responses to these items were either "yes" or "no." The survey did not ascertain further information regarding adoption of the characteristics.

155. See BRUDNEY, supra note 8 , at 84 . 
TABLE 7

CHARACTERISTICS ADOPTED BY SAMPLE OF GOVERNMENT-BASED VOLUNTEER PROGRAMS

\begin{tabular}{lc}
\hline Characteristic & $\begin{array}{c}\text { Percentage } \\
\text { of Programs }\end{array}$ \\
\hline Recognition Activities for Volunteers & 91.0 \\
Formal Record-Keeping on Volunteers & 79.8 \\
Basic Training for Volunteers & 78.7 \\
Written Policies Governing the Volunteer Program & 78.2 \\
Active Outreach to Recruit New Volunteers & 76.1 \\
Support from High-Level Officials for the Volunteer Program & 74.5 \\
Job/Position Descriptions for Volunteers & 72.3 \\
Ongoing or In-Service Training for Volunteers & 62.8 \\
Liability Insurance Coverage for Volunteers & 62.2 \\
Orientation for New Volunteers & 55.9 \\
Training for Employees Who Work with Volunteers & 53.7 \\
Reimbursement for Work-Related Expenses of Volunteers & 48.9 \\
Budget for the Volunteer Program & 47.9 \\
Volunteers with Responsibility for Managing & 39.4 \\
Other Volunteers & \\
Newsletter for Volunteers & 37.2 \\
Annual or Other Evaluation of Volunteers & 30.3 \\
\hline
\end{tabular}

About three-fourths of the volunteer coordinators report that they practice active outreach to recruit volunteers, and that their programs enjoy the support of high-level organizational officials. As Ellis observes, such support can be difficult to obtain. ${ }^{156}$ More than seventy percent of the coordinators state that their volunteer program makes use of a fundamental building block in volunteer administration: job descriptions for the positions staffed by volunteers.

Several of the best practices listed in Table 7 assess the level of training provided by host organizations to support a volunteer workforce. Approximately eighty percent of the sample programs reportedly offer basic training for volunteer workers. Many fewer, slightly more than half, provide orientation for new volunteers. More than sixty percent provide ongoing or inservice training for volunteers as they assume new responsibilities. Finally,

156. See ELLIS, supra note 109, at 1 . The difficulty of obtaining support is a theme in Ellis's book. 
slightly more than one-half of the programs surveyed state that they train employees who work with volunteers.

Each of the best practices in Table 7 imposes a monetary cost on the sponsoring agency, but in some cases the costs are more readily apparent than others. Where the cost of a best practice is identifiable, fewer volunteer programs have adopted it. For example, less than one-half of the sample has a budget for the volunteer program or offers reimbursement for the work-related expenses of volunteers, and only $37.2 \%$ of the programs publish a newsletter for volunteers. Substantially more of the volunteer programs, $62.2 \%$, provide liability insurance coverage for volunteers, according to the sample of program coordinators.

Relatively few agencies entrust responsibility to volunteers for managing other volunteers, despite its putative advantages for continuing volunteer motivation and retention. ${ }^{157}$ Finally, the best practice used least often is annual or other evaluations of volunteers; this finding is consistent with other research. $^{158}$

Table 8 investigates the question of whether the program characteristics recommended in the literature of volunteer administration have been adopted at the same rate by volunteer programs operating at different levels of government. An analysis of variance procedure was performed for each characteristic to determine if the differences in percentages across government levels are sufficiently large to warrant rejecting the null hypothesis that the percentages are indistinguishable statistically, based on the F-test of statistical significance. By presenting this information by level of government, the table not only corrects for any bias introduced by the composition of the sample but also identifies which level of government is the leader in adopting the recommended characteristics.

Table 8 adds one important program feature to the list in Table 7: the percentage of time on the job that the volunteer coordinator devotes to managing or working with the volunteers. As discussed above, job titles notwithstanding, most volunteer coordinators do not spend all or even a majority of their work time managing the program; they have other major job responsibilities. That finding is substantiated in the present sample as well. The mean percentage of time devoted to managing the volunteers ranged from a low of $28.6 \%$ in the federal programs to a high of $37.7 \%$ in the state programs. ${ }^{159}$

157. See FISHER \& COLE, supra note 109, at 65. Because legitimate authority is taken very seriously, it is not so surprising that government agencies did not adopt this best practice with great frequency.

158. See, e.g., Natalie J. Allen, The Role of Social and Organizational Factors in the Evaluation of Volunteer Programs, 10 EVALUATION \& PROGRAM PLANNING 257, 257 (1987).

159. For the sample as a whole, the mean percentage was 32.35 , with a standard deviation of 30.04 . 
TABLE 8

ADOPTION OF RECOMMENDED VOLUNTEER PROGRAM

CHARACTERISTICS BY LEVEL OF GOVERNMENT $\dagger$

\begin{tabular}{|c|c|c|c|c|}
\hline \multirow[b]{2}{*}{ Characteristic } & \multicolumn{4}{|c|}{ Level of Government (in percentages) } \\
\hline & Federal & State & Local & Combination \\
\hline Recognition for Volunteers & 90.0 & 90.0 & 87.8 & 100.0 \\
\hline Record-Keeping for Volunteers & 93.8 & 60.0 & 75.5 & $68.0 * * *$ \\
\hline Basic Volunteer Training & 73.8 & 73.3 & 85.7 & $96.0 *$ \\
\hline Written Policies for Program & 93.8 & 63.3 & 63.3 & $88.0 * * *$ \\
\hline Outreach to Recruit Volunteers & 70.0 & 86.7 & 73.5 & 84.0 \\
\hline $\begin{array}{l}\text { High-level support for Volunteer } \\
\text { Program }\end{array}$ & 83.8 & 56.7 & 71.4 & $76.0^{*}$ \\
\hline $\begin{array}{l}\text { Job Descriptions for Volunteer } \\
\text { Positions }\end{array}$ & 80.0 & 66.7 & 59.2 & $84.0 *$ \\
\hline On-going Training for Volunteers & 65.0 & 66.7 & 51.0 & 80.0 \\
\hline Insurance for Volunteers & 68.8 & 60.0 & 51.0 & 76.0 \\
\hline Orientation for New Volunteers & 73.8 & 46.7 & 34.7 & $60.0 * * *$ \\
\hline $\begin{array}{l}\text { Training for Employees Who Work } \\
\text { with Volunteers }\end{array}$ & 60.0 & 50.0 & 36.7 & $80.0^{* *}$ \\
\hline Reimbursement for Expenses & 70.0 & 33.3 & 26.5 & $44.0^{* * *}$ \\
\hline Budget for Volunteer Program & 51.3 & 40.0 & 49.0 & 44.0 \\
\hline $\begin{array}{l}\text { Volunteers who Manage Other } \\
\text { Volunteers }\end{array}$ & 27.5 & 46.7 & 38.8 & $72.0^{* * *}$ \\
\hline Newsletter for Volunteers & 27.5 & 50.0 & 32.7 & $56.0 *$ \\
\hline Evaluation of Volunteers & 32.5 & 36.7 & 18.4 & 40.0 \\
\hline $\begin{array}{l}\text { Percentage of Time Devoted to } \\
\text { Managing Volunteers }\end{array}$ & 28.6 & 37.7 & 35.7 & 32.2 \\
\hline $\mathrm{N}$ & 80 & 30 & 49 & 25 \\
\hline
\end{tabular}

$\dagger \quad$ For "Percentage of Time Devoted to Managing Volunteers," the table presents mean scores by level of government. For this characteristic, the N's differ slightly from the rest of those listed: Federal ( $\mathrm{N}=80$ ); State (30); Local (48); and Combination (24). The test of statistical significance applied is the F-test in analysis of variance for differences in means (percentage of time devoted to managing volunteers) or differences in percentages (all other characteristics).

* Difference in percentages statistically significant at $\mathrm{p}<.05$

** Difference in percentages statistically significant at $\mathrm{p}<.01$

*** Difference in percentages statistically significant at $\mathrm{p}<.001$

The results in Table 8 show that for seven of the recommended program characteristics, the rates of adoption do not differ significantly across the sample 
by government level. ${ }^{160}$ These seven characteristics include the percentage of time devoted by the coordinator to managing the volunteers, active outreach to recruit volunteers, a budget dedicated to the volunteer program, recognition activities for volunteers, ongoing or in-service training for volunteers, annual or other evaluations of volunteers, and liability insurance coverage for volunteers. These findings suggest that at least for this sample, volunteer programs at different levels of government have done equally well—or poorly-at adopting the particular features. ${ }^{161}$

For the ten other characteristics in the table, however, the rates of implementation vary significantly by level of government in a highly consistent pattern. Volunteer programs sponsored by the federal government or by a combination of government levels rank either first or second in the rate of adoption of six characteristics-training for employees who work with volunteers, written policies governing the volunteer program, orientation for new volunteers, high-level support for the volunteer program, job descriptions for volunteer positions, and reimbursement for volunteers for work-related expenses. By contrast, the rate of adoption is much less for the volunteer programs housed in state or local governments. The same pattern holds for liability insurance coverage for volunteers, although, as noted above, the differences in percentages by government level do not attain statistical significance. ${ }^{162}$ In a few cases-volunteers manage other volunteers and a newsletter for the volunteer program - the combination programs rank highest in adoption of a recommended feature, with the federal programs lagging far behind. In one instance, record-keeping for volunteers, this pattern is reversed.

For only two characteristics do volunteer programs sponsored by the federal government or by a combination of governments fail to achieve the highest rate of implementation-work time devoted by the coordinator to managing volunteers and outreach activities to recruit volunteers. For these characteristics, state government organizations have the highest rate. However, as noted above, the differences in adoption of these best practices by government level do not attain statistical significance. For another four characteristics-volunteers manage other volunteers, a newsletter for volunteers, basic training for volunteers, and record-keeping for themprograms sponsored by state or local governments rank second in the rate of implementation.

The results in Table 8 strongly suggest that the volunteer programs sponsored by the federal government or by a combination of governments are the leaders in adopting the features recommended in the literature on volunteer administration. In general, smaller percentages of the state and local

160. The rates do not differ significantly at $\mathrm{p}<.05$, that is, they are not statistically significant at the five percent (.05) level.

161. Table 7 displays the gross rate of adoption of the various characteristics across the sample of government-based volunteer programs.

162. Although the differences in percentages on this characteristic do not achieve statistical significance at $\mathrm{p}<.05$, the differences are significant at $\mathrm{p}<.10$. 
government-based programs have adopted these characteristics. To the extent that the characteristics qualify as "best practices" and are associated with desired outcomes from volunteer involvement, state and local governmentbased programs would be expected to fall behind as well in volunteer program performance.

The final goal of the research was to explore whether the best practices are related to the benefits realized by these programs in the public sector. The possible relationship between the adoption of these design and management features and the benefits achieved by the program have not previously been examined empirically.

To undertake this analysis, the only measure of program performance available through the mail survey is a summative measure of the benefits achieved by the volunteer program, as perceived by the volunteer coordinators in the sample. The questionnaire asked the coordinators to indicate whether their program had achieved any of eleven benefits thought to accrue from volunteer involvement - the capability to provide services the agency could not otherwise provide, cost savings to government, increases in the level of services or programs provided by the agency, infusion of specialized skills possessed by volunteers, increased public support for agency programs, improved quality of services or programs provided by the agency, increased client or citizen satisfaction, expansion of the kinds of services or programs the agency can offer, feedback or suggestions from volunteers on how to improve services, more detailed attention to clients, and expansion of personnel to work during emergencies and peak load periods. ${ }^{163}$ Responses to these eleven items were used to create an index of the total number of benefits achieved by the volunteer program. ${ }^{164}$

One should consider two possible influences on the data when linking the recommended best practices for volunteer programs to the benefits index in empirical analysis. First, the volunteer coordinators in the sample may be too willing to perceive benefits emanating from their programs. Although the mail survey was anonymous and confidential, and the results were not shared with the hierarchical superior to the volunteer coordinator or with other officials in the agency, the respondents may be overly eager to attribute benefits to an activity that occupies, on average, approximately one-third of their work time by their own reports. This potential bias might increase with the amount of time the volunteer coordinator reports devoting to the program. Second, as in any bivariate, or two-variable, relationship, the possibility of spuriousness

163. Measuring volunteer program performance is very difficult. Validated performance measures do not exist, and empirical analyses almost always rely on perceptual measures, such as those used here. The list of possible benefits to host organizations from volunteer involvement employed in the present study builds on discussions of these benefits in the literature. See, e.g., ELLIS, supra note 109, at 8-11, 14-15; MCCURLEY \& LYNCH, supra note 109, at 149-54.

164. Responses to each of the 11 benefit items were either "yes" (benefit achieved) or "no" (benefit not achieved). The survey questionnaire did not include gradations of the extent to which the benefit might have been achieved. 
exists, that is, an observed statistical relationship may be the by-product of a third factor that affects both variables. For example, the relationship between the application of best practices to volunteer programs and the perceived benefits might be a result of the size or resources of the host agency. Larger, well-funded agencies would be expected to sponsor volunteer programs that both adopted more recommended features and achieved greater benefits.

These influences cannot be confronted directly in the present analysis; however, countervailing evidence is available. First, every treatment of volunteer administration warns as well as encourages the volunteer coordinator and the host organization to allocate significant time to volunteer administration and management. ${ }^{165}$ Management of unpaid workers requires a substantial investment of the manager's time and expertise if the organization is to realize benefits from volunteer involvement. ${ }^{166}$ While the relationship between these variables might be inflated in empirical analysis due to the respondents' eagerness to justify a significant work activity, given the universal endorsement in the literature, it would be highly anomalous to find that devoting time to volunteer management was unrelated or negatively related to the attainment of perceived benefits from the program.

Second, Brudney and Kellough's analysis of volunteer programs in state government agencies offers some parenthetical evidence concerning possible spuriousness in the relationship between the application of best practices and perceived benefits emanating from these programs. ${ }^{167}$ These researchers examined the relationship between an index of the amount of recommended characteristics adopted by a program and the number of benefits attained. As in the present analysis, all measures were based on the perceptions of the volunteer coordinators; in fact, nearly all of the measures were identical to those used here. Because of the possibility of spuriousness in this relationship, Brudney and Kellough controlled statistically for the size and resources of the host agency in a multivariate regression analysis. ${ }^{168}$ The findings show that even with the controls, the index of best practices was related significantly ${ }^{169}$ to the number of benefits attained. As these authors conclude, "[i]n essence, the 'mere' possession of resources, as indicated by agency size, is not sufficient to assure benefits to an agency from the involvement of volunteers. These novel human resources must be marshaled and managed in a sound volunteer program." 170

165. See generally ELLIS, supra note 109; FISHER \& COLE, supra note 109; MCCURLEY \& LYNCH, supra note 109; THE VOLUNTEER MANAGEMENT HANDBOOK, supra note 22.

166. See generally Jean Baldwin Grossman \& Kathryn Furano, Making the Most of Volunteers, 62 LAW \& CONTEMP. PROBS. 199, 208-15 (Autumn 1999)

167. See generally Brudney \& Kellough, supra note 85.

168. The measures of size or resources were the number of full-time, paid employees in the host organization and the ratio of volunteer-to-paid personnel. The organizational budget was highly related to the first of these measures. See id. at $124 \&$ tbl. 7.

169. The index of best practices was related significantly at $\mathrm{p}<.05$.

170. See Brudney \& Kellough, supra note 85, at 124. 
Nevertheless, the limitations to this part of the analysis are important when reviewing the findings in Table 9, which presents the correlations between the adoption of recommended best practices and the perceived benefits. Using the sample of government-based volunteer programs, the table provides the Pearson product moment correlation coefficient (r) between the adoption of each recommended program characteristic and the index of perceived benefits. Characteristics at or near the top of the table have higher correlations with the benefits index and, thus, are associated more strongly with the attainment of benefits from the program, as perceived by the volunteer coordinators.

The largest correlation is between the percentage of work time devoted by the coordinator to managing or working with the volunteers and the index of perceived benefits from the program. This correlation should be interpreted with particular caution because it may reflect to some extent the understandable interest of the volunteer coordinators in validating their investment of time in the volunteer program. The next two correlations also suggest the importance of the management of volunteers. Providing training for employees who work with volunteers and giving volunteers the responsibility to manage other volunteers appear to be equally effective in attaining benefits from the program. Providing ongoing or in-service training for volunteers, which might help prepare them for management responsibilities in the program, is associated somewhat less strongly with perceived benefits.

The next set of program characteristics is more diverse. The practitioner literature frequently addresses the difficulty of volunteer recruitment and the resulting need to pursue this challenge aggressively. Table 9 shows that active outreach to recruit volunteers is firmly associated with the attainment of perceived benefits. Creating a budget for the volunteer program and written policies to govern its operation bear comparable relationships with the benefits index. Although used by less than half of the sample of government-based volunteer programs, a newsletter for the volunteers may be a good investment considering its association with the realization of perceived benefits. Recognition activities for volunteers, which by contrast have the highest rate of application of any program characteristic across the sample, has virtually the same correlation with the benefits index. 
TABLE 9

CORRELATIONS BETWEEN ADOPTION OF

RECOMMENDED VOLUNTEER PROGRAM CHARACTERISTICS

AND PERCEIVED BENEFITS OF USING VOLUNTEERS

\begin{tabular}{lc}
\hline Characteristic & Correlation \\
\hline Percentage of Work Time Devoted to Managing Volunteers & $.422^{* *}$ \\
Training for Employees who Work with Volunteers & $.346^{* *}$ \\
Volunteers who have Responsibility for Managing Other Volunteers & $.343^{* *}$ \\
Active Outreach to Recruit New Volunteers & $.339^{* *}$ \\
Budget for the Volunteer Program & $.335^{* *}$ \\
Written Policies Governing the Volunteer Program & $.328^{* *}$ \\
Orientation for New Volunteers & $.314^{* *}$ \\
Newsletter for Volunteers & $.306^{* *}$ \\
Recognition Activities for Volunteers & $.305^{* *}$ \\
Support from High-level Officials for the Volunteer Program & $.290^{* *}$ \\
Job/position Descriptions for Volunteers & $.275^{* *}$ \\
Ongoing or In-service Training for Volunteers & $.266^{* *}$ \\
Annual or Other Evaluation of Volunteers & $.211^{*}$ \\
Liability Insurance Coverage for Volunteers & $.202^{*}$ \\
Basic Training for Volunteers & .104 \\
Formal Record-Keeping on Volunteers & .043 \\
Reimbursement for Work-Related Expenses of Volunteers & -.022 \\
\hline$*$ Correlation statistically significant at $\mathrm{p}<.01$ & \\
$* *$ Correlation statistically significant at $\mathrm{p}<.001$ &
\end{tabular}

While associated with the attainment of perceived benefits, the next two program characteristics have less apparent connection with the index than might have been anticipated. Gaining support from high-level officials for the volunteer program and creating job descriptions for volunteer positions are highly recommended in the volunteer administration literature; however, these features are near the bottom of the list with respect to their correlations with perceived benefits.

The remaining characteristics demonstrate scant or no apparent relationship to the realization of benefits from the volunteer program. Evaluation of volunteer performance is controversial, and perhaps not coincidentally, the practice of conducting annual or other evaluations of volunteers bears only a modest correlation to the benefits index. Basic training for volunteers is not related significantly to the benefits measure. Sponsoring agencies might do much better by conducting orientation on being a volunteer in a government 
organization, a practice that has a much more robust association with the achievement of perceived benefits listed in Table 9 .

Three of the last four program characteristics are procedural features. Two of them yield no apparent benefits: formal record-keeping for volunteers and reimbursement for their work-related expenses. Other research also has questioned the efficacy of reimbursement practices for volunteer workers. ${ }^{171}$ The third characteristic, providing liability insurance coverage for volunteers, has a modest relationship with the benefits index. Despite these marginal effects, it likely will prove necessary to keep accurate records of volunteer contributions, maintain a policy for volunteer reimbursement, and provide liability insurance coverage for unpaid workers. Although necessary, these practices likely will result in few perceived benefits.

\section{VII}

\section{CONCLUSION}

Given the close ideological and empirical identification between volunteer involvement and the nonprofit sector, this research has demonstrated that volunteer programs sponsored by government agencies are more prevalent than might have been anticipated. Available data indicate that volunteering to government is widespread, affecting a huge volume and variety of public services and organizations, as well as clients, employees, and citizen volunteers. Although nonprofit organizations predominate in the use of volunteers, national surveys show that government-based programs account for an estimated twenty-five to thirty percent of all volunteer effort.

The present research has examined this activity, and based on literature in the field, offered a definition of volunteer programs in the public sector. The volunteer activity is sponsored by a government agency and, thus, occurs in an organizational context; remuneration is not provided for volunteers' contributions, but reimbursement for their expenses is permitted; the time is given freely to benefit clients of government agencies, yet volunteers may certainly benefit as well; the work fulfills ongoing responsibilities of the host agency for delivering services or maintaining the organization.

Given this definition, the research analyzed the magnitude, scope, and monetary value of volunteer activity in the public sector. According to a 1992 Gallup survey, approximately twenty-seven percent of all volunteers donated time to a government organization in 1991, contributing time and talents worth an estimated fifty-five billion dollars to the sponsoring agencies. In 1993, the total hours volunteered to the public sector amounted to 2.3 million full-time employees, the equivalent of nine percent of government employment. The study found that volunteers are active at all levels of government, especially local—city and county_-governments.

\footnotetext{
171. See BRUDNEY, supra note 8 , at 29-30.
} 
The analysis considered the adoption by host government organizations of recommended best practices for volunteer programs, developed from a review of the literature in the field. Previous research has not investigated the extent to which these features have been applied in government or nonprofit organizations, or the equally crucial question of the possible relationship between the best practices and the perceived benefits yielded by the volunteer program. The data for analysis consisted of a broad sample of volunteer programs at all levels of government operating in a variety of policy domains; however, the sample is biased toward the federally supported programs.

Across the sample, reported application of the recommended features ranged from a high of ninety-one percent of the programs for the most prosaic practice-recognition activities for volunteers-to a low of $30.3 \%$ for the most problematic - annual or other evaluation of volunteers. When the rates of adoption were examined by level of government, a procedure which corrects for the over-representation of the federal programs, the leaders in application are the volunteer programs sponsored by the federal government or by a combination of governments. Comparatively fewer programs housed in state and local governments have adopted most of the recommended characteristics.

The final step in the empirical analysis was more exploratory, investigating the relationship between the adoption of recommended best practices and the attainment of perceived benefits from the volunteer program. Due to possible limitations in this analysis that can be addressed only partially, the findings here must be more speculative. The results suggested that most of the recommendations in the literature for creating and managing a volunteer program seem to have merit. Reported application of all but three of thembasic training for volunteers, formal record-keeping for volunteers, and reimbursement for their work-related expenses-was associated statistically with the realization of benefits from volunteer involvement, as perceived by the sample of volunteer coordinators. The characteristics that seemed to build management capacity of the program tended to be more strongly associated with perceived benefits.

Despite the limitations acknowledged throughout, a certain urgency attends the analysis of recommended best practices in volunteer administration. Nothing comparable appears in the literature, yet volunteer coordinators in government and the nonprofit sector are challenged daily to design and operate effective programs using unpaid personnel. Several studies as well as popular accounts suggest serious deficiencies in the field. ${ }^{172}$ According to one study, "managing volunteers effectively is a problem for many not-for-profit organizations.... [T] hese organizations could accomplish even more if they could better recruit, manage and recognize the work of volunteers... . The

172. For a review and analysis of these studies and accounts, see Jeffrey L. Brudney, The Perils of Practice: Reaching the Summit, 9 NONPROFIT MGMT. \& LEADERSHIP 391-95 (1999). 
findings substantiate a crisis in volunteer management." ${ }^{, 173}$ In light of such assessments, some guidance, no matter how preliminary, may be useful.

As in any initial or exploratory inquiry, the weaknesses identified in the present research indicate areas for further study. First, the perceptual measures employed in the analysis lack precision. It would be useful to assess at a finer level the program characteristics recommended in the literature of volunteer administration and the realization of benefits from volunteer involvement. Second, the sample of government-based volunteer programs lacks representativeness, although the parameters of the population remain elusive. The marketing study that generated the sample encountered problems in identifying the public agencies that use volunteers, locating knowledgeable contacts within some agencies, and underwriting the considerable expense of the inquiry. It will not be easy or inexpensive to develop an appropriate sampling frame to examine these programs more systematically. If electronic mailing addresses could be obtained for volunteer coordinators in the public sector, however, internet technology may be used to survey a larger, more representative sample. ${ }^{174}$

Finally, an important question awaiting further research is how the volunteer program characteristics examined here as possible best practices for the public sector may translate to the nonprofit sector, a much larger employer of volunteer labor. Much more so than nonprofit organizations, government agencies are known, and castigated, for elaborate organizational structures, policies, and procedures that may spill over into volunteer program design and management. An interesting empirical question is whether and how administrative practices and procedures for volunteer programs-and their results-may differ across sectors. Little comparative research has examined this issue. A 1990 symposium in the journal Nonprofit and Voluntary Sector Quarterly did uncover some intriguing differences, ${ }^{175}$ but calls for systematic comparison of volunteers and volunteer programs across sectors have gone largely unheeded. ${ }^{176}$ In this era of fiscal stringency, when both government and nonprofit organizations must strive for the greatest return on all their resources, perhaps the need to evaluate best practices for volunteer programs may inspire the kind of cross-sectoral research that will begin to answer these and other pressing questions.

173. United Parcel Service, Managing Volunteers: A Report to UPS 1 (1998).

174. I am grateful to Professor Marc Musick, University of Texas at Austin, for this suggestion.

175. The symposium, "Volunteers in Public and Nonprofit Settings," was published in 19 NONPROFIT \& VOLUNTARY SECTOR Q. (1990).

176. See David Horton Smith, Determinants of Voluntary Association Participation and Volunteering: A Literature Review, 23 NONPROFIT \& VOLUNTARY SECTOR Q. 243 (1994). Smith concludes that the study of contextual variables, including organizational type, "is much less developed than other areas of research on volunteer participation." Id. at 246. 